\title{
Effect of graded doses of pentagastrin in patients with and without gastritis
}

\author{
A. BERSTAD AND J. MYREN \\ From the Laboratory of Gastroenterology, Department IX, Ullevaal Hospital, Oslo, Norway
}

SUMMARY The effect of graded doses of pentagastrin on the gastric scretion of acid was compared in patients with and without gastritis. Biopsies were taken from the body of the stomach. Ten subjects had normal gastric mucosa, eight had superficial gastritis, and 10 atrophic gastritis. Pentagastrin in a dose of $1.5 \mu \mathrm{g} / \mathrm{kg} / \mathrm{hr}$ elicited a near maximal $\mathrm{HCl}$ response from both the normal gastric mucosa and the mucosa with gastritis. The response to $0.3 \mu \mathrm{g} /$ $\mathrm{kg} / \mathrm{hr}$ was significantly lower than the response to $7.5 \mu \mathrm{g} / \mathrm{kg} / \mathrm{hr}$ in the subjects with atrophic gastritis, while there was no significant difference in the response between the dose levels in the subjects with a normal mucosa.

The dose level of pentagastrin, which will elicit a maximal $\mathrm{HCl}$ response from the gastric mucosa when given as a continuous intravenous infusion, has been determined in healthy subjects and in patients with duodenal ulcer (Halter, Bürki, and Richterich, 1968; Kaess, Gugler, and Eichelbaum, 1968 and 1969; Multicentre Study, 1967; Multicentre Pilot Study, 1967; Konturek, 1967; Konturek and Lankosz, 1967; Mason, Giles, and Clark, 1969; Wormsley, Mahoney, and $\mathrm{Ng}, 1966$ ). The dose response relationship of the pentagastrin-stimulated $\mathrm{HCl}$ secretion and the dose of pentagastrin required for maximal stimulation of the parietal cells in a gastric mucosa with gastritis has not been shown previously.

\section{Material and Methods}

Twenty-eight subjects were examined. Two gastric biopsies were taken under fluoroscopic control with a biopsy capsule for multiple biopsies from the body of the stomach, about $10 \mathrm{~cm}$ beyond the cardia. One biopsy was fixed with formalin, embedded in paraffin, and stained with haematoxylin and eosin for histological examina-

${ }^{1}$ This work was supported by a grant from Norges Almenvitenskapelige Forskningsråd. tion. The histology was classified as normal, superficial gastritis, and atrophic gastritis (Burhol, Myren, and Reichborn-Kjennerud, 1968). Ten subjects had a normal gastric mucosa (nine men and one woman), average age 47 years (range 15-72 years). Eight subjects had superficial gastritis (three men and five women), average age 54 years (41-68 years). Ten subjects had atrophic gastritis (six men and four women), average age 59 years (26-77 years).

The other biopsy was frozen immediately on dry ice and used for the histochemical demonstration of the succinic dehydrogenase (SD) activity of the gastric mucosa according to a technique already described (Burhol and Myren, 1968). The number of the SD-active parietal cells was counted in the correctly orientated sections in $100.1 \mathrm{~mm}$ broad columns perpendicular to the mucosal surface. The thickness of the parietal cell layer was measured. The number of the parietal cells was calculated per $\mathrm{mm}^{2}$ mucosal surface and per $\mathrm{mm}^{3}$ (the density of the parietal cells) of the parietal cell layer (Table I).

The gastric secretion of acid was examined in the fasting subjects. A Levin tube was introduced to the most dependent part of the stomach with the aid of fluoroscopy. The gastric juice was aspirated continuously and sampled in 15-minute portions. The unstimulated juice was 
aspirated during two 15 -minute periods. Pentagastrin, dissolved in $0.15 \mathrm{M} \mathrm{NaCl}$, was given as a continuous intravenous infusion by a motor pump at $12 \mathrm{ml} /$ hour. Graded doses of $0.3,1.5$, and $7.5 \mu \mathrm{g} / \mathrm{kg} / \mathrm{hr}$ of pentagastrin were administered during five 15-minute periods respectively. The dose levels were increased successively without intervals.

Hydrochloric acid was determined by automatic titration to $p \mathrm{H} 7.4$ (Radiometer, Copenhagen). At each dose level the last two 15minute samples of gastric juice was taken to represent the maximal response to the applied dose of pentagastrin. The results are given as mean values for the groups.

The statistical significance of the differences between means were evaluated by Student's t test. The calculated maximal $\mathrm{HCl}$ response from the gastric mucosa was estimated according to the method of Makhlouf, McManus, and Card (1966) by the intercepts on the $y$ axis of the regression lines in Figure 4.

\section{Results}

THE HCL RESPONSE TO $0.3 \mu \mathrm{G} / \mathrm{KG} / \mathrm{HR}$ OF PENTAGASTRIN

In the subjects" with a normal gastric mucosa the maximal output of $\mathrm{HCl}$ after $0.3 \mu \mathrm{g} / \mathrm{kg} / \mathrm{hr}$ of pentagastrin was on average $85 \%$ of the maximal response to $7: 5 \mu \mathrm{g} / \mathrm{kg} / \mathrm{hr}$. The difference in response between the dose levels was not significant. In the subjects with atrophic gastritis the

\begin{tabular}{|c|c|c|}
\hline & \multicolumn{2}{|c|}{ Number of Parietal Cells $( \pm S E M)$} \\
\hline & $\begin{array}{l}\text { Per } \mathrm{mm}^{2} \text { Mucosal } \\
\text { Surface }\end{array}$ & $\begin{array}{l}\text { Per } \mathrm{mm}^{3} \text { Parietal } \\
\text { Cell Layer }\end{array}$ \\
\hline $\begin{array}{l}\text { Normal mucosa } \\
\text { Superficial gastritis }\end{array}$ & $\begin{array}{l}58,900( \pm 3,400) \\
41,400( \pm 4,600) \\
t=3 \cdot 11, P<0.01\end{array}$ & $\begin{array}{l}79,120( \pm 4,430) \\
69,400( \pm 4,040) \\
t=1 \cdot 59, \mathrm{P}>0 \cdot 01\end{array}$ \\
\hline Atrophic gastritis & $\begin{array}{l}26,300( \pm 4,200) \\
t=6.06, P<0.001\end{array}$ & $\begin{array}{l}45,880( \pm 6,150) \\
t=4.39, P<0.01\end{array}$ \\
\hline
\end{tabular}

Table I Number of SD-active parietal cells in the three groups ${ }^{1}$

${ }^{1}$ The significances of the differences between the normal groups and those with gastritis are indicated by the $t$ and $P$ values. maximal output of $\mathrm{HCl}$ after $0.3 \mu \mathrm{g} / \mathrm{kg} / \mathrm{hr}$ of pentagastrin was $66 \%$ of the response to 7.5 $\mu \mathrm{g} / \mathrm{kg} / \mathrm{hr}$. The difference in response between the dose levels was significant $(P<0.05)$. The results are set out in Tables $I$ and II and in Figures 1, 2, and 3.

THE HCl RESPONSE TO $1.5 \mu \mathrm{G} / \mathrm{KG} / \mathrm{HR}$ OF PENTAGASTRIN

In the subjects with a normal gastric mucosa the maximal output after $1.5 \mu \mathrm{g} / \mathrm{kg} / \mathrm{hr}$ of pentagastrin was on average $102 \%$ of the response to $7.5 \mu \mathrm{g} / \mathrm{kg} / \mathrm{hr}$ and $91 \%$ of the response in those with atrophic gastritis (Figs. 1, 2, and 3 and Table II). The difference in response between the dose levels was not significant.

THE HCl RESPONSE TO $7 \cdot 5 \mu \mathrm{G} / \mathrm{KG} / \mathrm{HR}$ OF PENTAGASTRIN

The values for the calculated maximal output of $\mathrm{HCl}$ were lying close to the values obtained with $7.5 \mu \mathrm{g} / \mathrm{kg} / \mathrm{hr}$ of pentagastrin (Table III). The slope of the regression lines in Fig. 4 was not significantly different between the subjects with normal gastric mucosa and those with superficial and atrophic gastritis.

\begin{tabular}{lll}
\hline & $\begin{array}{l}\text { Calculated Maximal } \\
\text { HCl Response } \\
\text { (m-equiv/30 min) }\end{array}$ & $\begin{array}{l}\text { HCl Response to } \\
7.5 \mu g / k g / h r\end{array}$ \\
& & $\begin{array}{l}\text { Pentagastrin } \\
\text { (m-equiv } / 30 \text { min) }\end{array}$ \\
& & 16.1 \\
Normal mucosa & 16.0 & 10.9 \\
Superficial gastritis & 11.0 & 8.9
\end{tabular}

Table III Calculated maximal $\mathrm{HCl}$ response and response to $7.5 \mu \mathrm{g} / \mathrm{kg} / \mathrm{hr}$ of pentasgastrin

\section{Discussion}

The single biopsy used for the histological classification in the present study may not be representative for the whole gastric mucosa. The alterations in the mucosa in the subjects

\begin{tabular}{|c|c|c|c|c|c|c|}
\hline & \multicolumn{3}{|c|}{ Pentagastrin $0.3 \mu \mathrm{g} / \mathrm{kg} / \mathrm{hr}$} & \multicolumn{3}{|c|}{ Pentagastrin $1.5 \mu \mathrm{g} / \mathrm{kg} / \mathrm{hr}$} \\
\hline & Output & Concenträtion & Volume & Output & Concentration & Volume \\
\hline $\begin{array}{l}\text { Normal mucosa } \\
\text { Significance } \\
\text { Superficial gastritis } \\
\text { Significance } \\
\text { Atrophic gastritis } \\
\text { Significance }\end{array}$ & $\begin{array}{l}85 \pm 12 \\
N S \\
74 \pm 9 \\
P<0.05 \\
66 \pm 14 \\
P<0.05\end{array}$ & $\begin{array}{l}89 \pm 3 \\
P<0.01 \\
95 \pm 5 \\
N S \\
90 \pm 11 \\
N S\end{array}$ & $\begin{array}{l}95 \pm 12 \\
N S \\
82 \pm 7 \\
P<0.05 \\
69 \pm 7 \\
P<0.01\end{array}$ & $\begin{array}{l}102 \pm 8 \\
\text { NS } \\
95 \pm 8 \\
\text { NS } \\
91 \pm 8 \\
\text { NS }\end{array}$ & $\begin{array}{l}98 \pm 2 \\
\mathrm{NS} \\
98 \pm 3 \\
\mathrm{NS} \\
92 \pm 4 \\
\mathrm{NS}\end{array}$ & $\begin{array}{l}104 \pm 8 \\
\text { NS } \\
98 \pm 8 \\
\text { NS } \\
98 \pm 8 \\
\text { NS }\end{array}$ \\
\hline
\end{tabular}

Table II The $\mathrm{HCl}$ response to pentagastrin 0.3 and $1.5 \mu \mathrm{g} / \mathrm{kg} / \mathrm{hr}( \pm S E M)$ and as a percentage of the response to $7 \cdot 5 \mu \mathrm{g} / \mathrm{kg} / \mathrm{hr}^{1}$

${ }^{t}$ Significance $=$ the significance of the difference between the response to $7.5 \mu \mathrm{g} / \mathrm{kg} / \mathrm{hr}$ and the response to 0.3 and $1,5 \mu \mathrm{g} / \mathrm{kg} / \mathrm{hr}$. $\mathrm{NS}$ $=$ not significant $(P>0,05)$, 


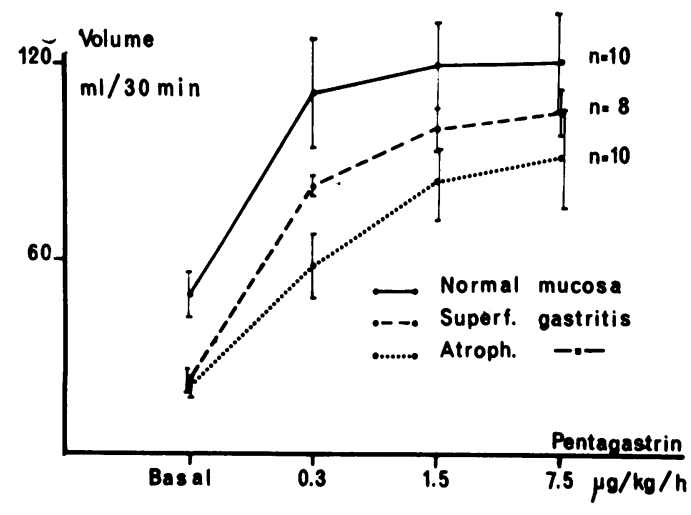

Fig. 1 Dose response curves for volume of gastric juice in response to intravenous infusion of pentagastrin.

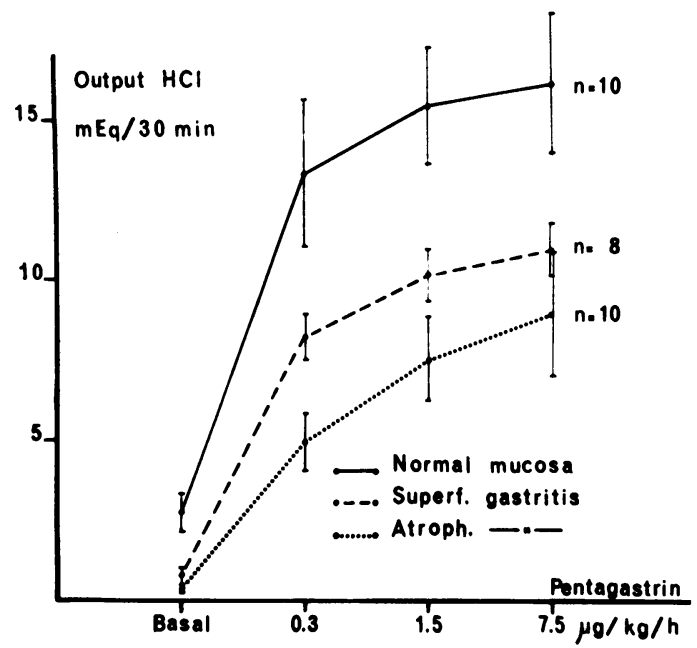

Fig. 3 Dose response curves for $\mathrm{HCl}$ output in response to intravenous infusion of pentagastrin.

with gastritis was, however, also indicated by the reduction in number of the SD-active parietal cells in the biopsies examined histochemically.

The Multicentre Pilot Study (1967) suggested that a dose of $6.0 \mu \mathrm{g} / \mathrm{kg} / \mathrm{hr}$ of pentagastrin was necessary to obtain a maximal $\mathrm{HCl}$ response when the intravenous infusion technique was used. Mason et al (1969), Konturek (1967), and Konturek and Lankosz (1967) used a technique similar to that in the present study. They found that a dose of $1.2 \mu \mathrm{g} / \mathrm{kg} / \mathrm{hr}$ of pentagastrin was sufficient for maximal stimulation, and even $0.6 \mu \mathrm{g} / \mathrm{kg} / \mathrm{hr}$ gave a near maximal response in many of the subjects (Mason et al, 1969; Worms-

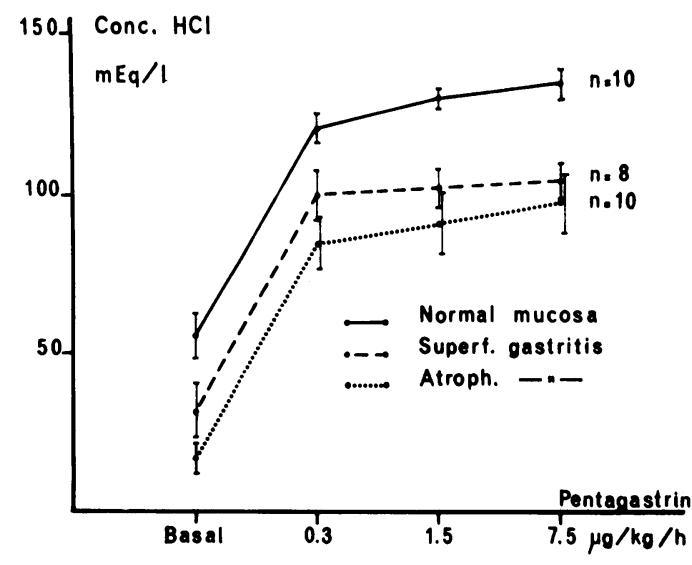

Fig. 2 Dose response curves for $\mathrm{HCl}$ concentration in gastric juice during intravenous infusion of pentagastrin.

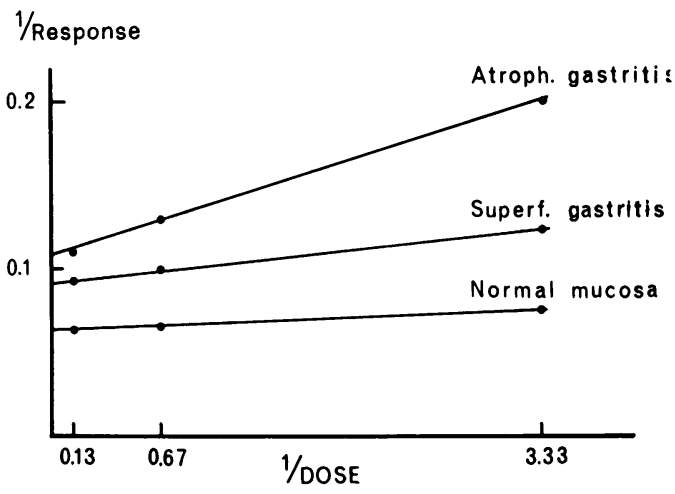

Fig. 4 Relationship between reciprocals of $\mathrm{HCl}$ response (m-equiv/30) and dose of pentagastrin $(\mu \mathrm{g} / \mathrm{kg} / \mathrm{hr})$ in the subjects with normal gastric mucosa $(y=0.0037 x+0.0626)$, superficial gastritis $(y=0.0092 x+0.091)$, and atrophic gastritis $(y=0.0276 x+0.109)$.

ley et al, 1966). Mason et al (1969) found no difference in the results whether an interval between increasing doses was employed or not. The response to $1.2 \mu \mathrm{g} / \mathrm{kg} / \mathrm{hr}$ was not significantly different but well correlated with the values obtained with $0.4 \mu \mathrm{g} / \mathrm{kg} / \mathrm{hr}$ of histamine acid phosphate infusion. All these investigations were done in healthy subjects or in patients with duodenal ulcer. Wormsley and Mahoney (1967) did not find that the parietal cells of patients with duodenal ulcer were more sensitive to a lower dose rate of pentagastrin infusion or that they were maximally stimulated more easily than the parietal cells in normal subjects. After vagotomy, however, it has been observed that the pattern of the $\mathrm{HCl}$ response to graded doses of penta- 
gastrin is changed and that a higher dose of pentagastrin is needed for maximal acid secretion (Multicentre Study, 1967; Konturek, Wysocki, and Oleksy, 1968).

In the present study the $\mathrm{HCl}$ response to 7.5 $\mu \mathrm{g} / \mathrm{kg} / \mathrm{hr}$ of pentagastrin was not significantly different from the response to $0.3 \mu \mathrm{g} / \mathrm{kg} / \mathrm{hr}$ in the subjects with a normal gastric mucosa, while there was a significantly higher response in those with atrophic gastritis. This finding may suggest that the gastric mucosa with a severely reduced number of scattered parietal cells needs a higher dose of pentagastrin or an infusion for more than 45 to 75 minutes for obtaining a maximal $\mathrm{HCl}$ response. The findings, however, show that these fewer and more scattered parietal cells in the gastric mucosa of patients with gastritis was stimulated nearly maximally by intravenous infusion of $1.5 \mu \mathrm{g} / \mathrm{kg} / \mathrm{hr}$ of pentagastrin as were the parietal cells in the normal mucosa. Thus a dose of $1.5 \mu \mathrm{g} / \mathrm{kg} / \mathrm{hr}$ seems sufficient and a dose of $7.5 \mu \mathrm{g} / \mathrm{kg} / \mathrm{hr}$ unnecessarily high in nonvagotomized subjects for the clinical estimation of the $\mathrm{HCl}$-secreting capacity.

\section{References}

Burhol, P. G., and Myren, J. (1968). Dehydrogenase activity and gastric secretion in gastritis. Scand. J. Gastroent., 3, 387-394.

Burhol, P. G., Myren, J., and Reichborn-Kjennerud, S. (1968). Mucosal measitrement and gastric secretion in gastritis. Scand. J. Gastroent., 3, 339-345.
Halter, F., Bürki, U., and Richterich, R. (1968). Histamin- und Pentagastrininfusionstest. Schweiz. med. Wschr., 98, 305-307.

Kaess, H., Gugler, H., and Eichelbaum, M. (1968). Untersuchungen über die Magensaftsekretion nach Stimulation mit Pentagastrin (ICI 50 123). Klin. Wschr., 46, 93-97.

Kaess, H., Gugler, H., and Eichelbaum, M. (1969). DosiWirkungs-Beziehung zwischen Säuersekretion des Magens und Pentagastrin. Z. Gastroent., 7, 88-91.

Konturek, S. J. (1967). Gastrin-like pentapeptide ICI 50123: a potent gastric stimulant in man. Amer. J. dig. Dis., 12, 285-292.

Konturek, S. J., and Lankosz, J. (1967). Pentapeptide infusion test. Scand. J. Gastroent., 2, 112-117.

Konturek, S. J., Wysocki, A., and Oleksy, J. (1968). Effect of medical and surgical vagotomy on gastric response to graded doses of pentagastrin and histamine. Gastroenterology, 54, 392-400.

Makhlouf, G. M., McManus, J. P. A., and Card, W. I. (1966). Action of the pentapeptide (ICI 50123) on gastric secretion in man. Gastroenterology, 51,455-465.

Mason, M. C., Giles, G. R., and Clark, C. G. (1969). Continuous intravenous pentagastrin as a stimulant of maximal gastric acid secretion. Gut, 10, 34-38.

Multicentre Study (1967). The effect of vagotomy on gastric secretion elicited by pentagastrin in man. Lancet, 2, 534-536.

Multicentre Pilot Study (1967). Pentagastrin as a stimulant of maximal gastric acid response in man. Lancet, 1, 291-295.

Wormsley, K. G., and Mahoney, M. P. (1967). Parietal cell responsiveness in duodenal ulcer. Brit. med.J., 1, 278.

Wormsley, K. G., Mahoney, M. P., and Ng, M. (1966). Effects of a gastrin-like pentapeptide (ICI 50,123) on stomach and pancreas. Lancet, 1, 993-996. 